\title{
Pelaksanaan Prinsip Pelayanan Publik SAMSAT Medan Selatan dalam Meningkatkan Pemungutan Pajak Kendaraan Bermotor Roda Dua
}

\section{Implementation of The Principle SAMSAT Medan Selatan Public Services in Increasing Tax Collection of Two Wheeled Motor}

\author{
Dinda Emilia*, Muhammad Husni Thamrin Nasution, \\ Rosmala Dewi \& Indra Muda \\ Program Studi Administrasi Publik, Fakultas Ilmu Sosial dan Ilmu Politik, \\ Universitas Medan Area, Indonesia
}

\begin{abstract}
Abstrak
Pelayanan publik merupakan suatu bentuk layanan pemerintah kepada masyarakat. Dari latar belakang peneliti mengambil judul pelaksanaan prinsip pelayanan publik samsat medan selatan dalam meningkatkan pemungutan pajak kendaraan bermotor roda dua, dengan masalah sebagai berikut Bagaimana Pelaksanaan prinsip pelayanan publik SAMSAT Medan Selatan dalam meningkatkan pemungutan pajak kendaraan bermotor Roda Dua, penelitian ini menggunakan metode deskriptif kualitatif yang menggunakan teknik pengumpulan data yaitu observasi, wawancara, dan dokumentasi. Adapun hasil pembahasan menjelaskan bahwasanya pelaksanaan prinsip pelayanan samsat medan selatan cukup baik tetapi jika dilihat dari realisasi penerimaan pajak kendaraan bermotor roda dua terjadi penurunan dari tahun 2016 ke tahun 2017. Berdasarkan hasil penelitian dapat disimpulkan bahwa pelaksanaan prinsip pelayanan publik samsat medan selatan dalam meningkatkan pemungutan pajak kendaraan bermotor roda dua sudah cukup baik, tetapi yang harus ditingkatkan lagi adalah cara memotivasi masyarakat agar mau berpartisipasi membayar pajak khususnya kendaraan bermotor roda dua. Kata Kunci: Pelayanan public, SAMSAT, Pajak Kendaraan Bermotor
\end{abstract}

\begin{abstract}
Public services is a form of service provided by the bureaucracy or government to the public with the following problems : how does the implementation of Samsat Medan Selatan public service principles in increasing tax collection of motor vehicle tax, this research uses a descriptive qualitative method that uses data collection techniques, observation, interview, and documentation. Quite good but if seen from the realization of the tax revenue of two-wheeled motorbikes there was a decrease from 2016 to 2017 based on the results of the study it can be concluded that the Samsat southern field public service principle in increasing tax collection oftwo-wheeled motor vehicles is good enough, but what needs to be improved is how to motivate the public to want to participate in pay tax especially two-wheeled motor vehicles.
\end{abstract}

Keywords: Public Service, SAMSAT, Motorized Vehicle Tax

How to Cite: Emilia, D. Nasution, M.H.T. Dewi, R. \& Muda, I. (2019). Pelaksanaan Prinsip Pelayanan Publik Samsat Medan Selatan Dalam Meningkatkan Pemungutan Pajak Kendaraan Bermotor Roda Dua. Jurnal Ilmu Pemerintahan, Administrasi Publik, Ilmu Komunikasi (JIPIKOM), 1(1) 2019: 28-34,

*E-mail: dindaemilia@gmail.com

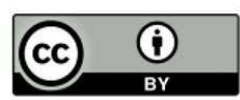




\section{PENDAHULUAN}

Pelayanan publik merupakan suatu bentuk layanan yang diberikan pemerintah kepada masyarakat. Pelaksanaan pelayanan publik dimaksudkan untuk memenuhi kebutuhan- kebutuhan yang sesuai dengan kebutuhan dan harapan masyarakat. Karena pada hakikatnya pemerintah merupakan abdi masyarakat atau public servant. Sesuai dengan UU N0.25 Tahun 2009 tentang pelayanan publik, pelayanan publik diartikan sebagai kegiatan atau rangkaian kegiatan dalam upaya memenuhi kebutuhan pelayanan yang sesuai dengan peraturan perundang-undangan bagi setiap warga negara atas barang dan jasa, maupun pelayanan administratif yang disediakan oleh penyelenggara pelayanan publik.

Sistem Administrasi Manunggal Satu Atap (SAMSAT) Medan Selatan merupakan salah satu instansi pemerintah yang bertugas memberikan pelayanan publik berupa dokumen administratif dan secara langsung kepada masyarakat. Kantor SAMSAT Medan Selatan juga merupakan salah satu unit pelayanan teknis (UPT) dari 3 instansi yaitu: Dinas Pendapatan Provinsi Sumatera Utara, POLRI, dan Jasa Raharja, yang melayani masyarakat yang akan membayar atau melunasi kewajibannya membayar pajak kendaraan bermotor. Sedangkan BANK SUMUT sebagai perpanjangan tangan Badan Pengelolaan Pendapatan Dan Retribusi Daerah (BPPRD) atau sebelumnya disebut Dispendasu dalam membantu pemungutan pajak dan Bank BRI sebagai perpanjangan tangan POLRI dalam menerima pembayaran PNBP (Penerimaan Negara Bukan Pajak) seperti STNK, TNKB, dan BPKB. Berdasarkan ulasan pada laman kantor samsat Medan Selatan bahwasanya banyak pendapat baik dan pendapat buruk yang disampaikan oleh masyarakat tentang pelayanan samsat tersebut. Salah satu adalah masih adanya petugas yang tidak ramah ketika wajib pajak meminta informasi serta dalam masalah ketepatan waktu, samsat Medan Selatan juga masih kurang dalam melayani masyarakat (Nasution, F.R. dan Rudi S.S., 2014).

Pelayanan pada dasarnya merupakan kegiatan atau manfaat yang ditawarkan oleh suatu pihak kepada pihak lain pada hakikatnya tidak berwujud serta tidak menghasilkan kepemilikan sesuatu, proses produksinya mungkin juga tidak diartikan dengan suatu produksi fisik. Pelayanan publik dapat diartikan sebagai pemberian layanan (melayani) keperluan orang atau masyarakat yang mempunyai kepentingan pada organisasi itu sesuai dengan aturan pokok dan tata cara yang telah ditetapkan (Sirait, 2011; Rinaldi, 2012). Menurut Sinambela (2011) pelayanan publik adalah pemenuhan keinginan dankebutuhan masyarakat oleh penyelenggara negara. Negara didirikan oleh publik (masyarakat) tentu saja dengan tujuan agar dapat meningkatkan kesejahteraan masyarakat. Pada hakikatnya Negara dan dalam hal ini pemerintah haruslah dapat memenuhi kebutuhan masyarakat. Kebutuhan dalam hal ini bukanlah individual akan tetapi berbagai kebutuhan yang sesungguhnya diharapkan oleh masyarakat. Menurut UU Nomor 25 tahun 2009 tentang pelayanan publik adalah kegiatan atau rangkaian kegiatan dalam rangka pemenuhan kebutuhan pelayanan sesuai dengan peraturan perundang-undangan bagi setiap warga Negara dan penduduk atas barang, jasa, dan/atau pelayanan administratif yang disediakan oleh penyelenggara pelayanan public. Menurut Mahmudi (2005) bahwa penyelenggaraan pelayanan publik harus berdasarkan: Kepastian Hukum, Keterbukaan, Partisipatif, Akuntabilitas, Kepentingan Umum, Profesionalisme, Keseimbangan hak dan kewajiban, Fasilitas dan perlakuan khusus bagi 
kelompok, Ketepatan waktu, Kecepatan, Kemudahan, dan Kejangkauan (Susanti, A., Kusmanto, H., \& Tarigan, U., 2018).

Pajak Kendaraan Bermotor adalah pajak atas pemilikan dan atau penguasaan kendaraan bermotor (Nasution, \& Sinaga, 2014; Sinulingga, Nasution, \& Batubara, 2018). Kendaraan bermotor adalah semua kendaraan beroda dua atau lebih beserta gandengannya yang digunakan di semua jenis jalan darat, dan digerakkan oleh peralatan teknik berupa motor atau peralatan lainnya yang berfungsi untuk mengubah suatu sumber daya energi tertentu menjadi tenaga gerak kendaran bermotor yang bersangkutan, termasuk alat-alat besar yang bergerak. Yang dimaksud dengan alat-alat berat dan alat- alat besar yang bergerak adalah alat yang dapat bergerak, berpindah tempat dan tidak melekat secara permanen. Pemungutan PKB didasarkan pada Undang-Undang Nomor 18 tahun 1997 tentang pajak daerah dan retribusi daerah sebagaimana telah diubah dengan Undang-Undang Nomor 34 tahun 2000 dan Peraturan Pemerintah Nomor 65 Tahun 2001 tentang pajak daerah. Selain itu, penerapan PKB pada suatu daerah provinsi didasarkan pada peraturan daerah provinsi yang bersangkutan yang merupakan landasan hukum operasional dalam teknis pelaksanaan pengenaan dan pemungutan PKB di daerah provinsi yang bersangkutan.

Objek PKB adalah pemilikan atau penguasaan kendaraan bermotor. Termasuk dalam objek PKB adalah kendaraan bermotor yang digunakan disemua jenis jalan darat, antara lain dikawasan bandara, pelabuhan laut, perkebunan, kehutanan, pertanian, pertambangan, industri, perdagangan, dan sarana olahraga dan rekreasi. Dasar pengenaan PKB dihitung sebagai perkalian dua unsur pokok yaitu: Nilai jual kendaraan bermotor $(\mathrm{NJKB})$ dan bobot yang mencerminkan secara relative radar kerusakan jalan dan pencemaran lingkungan akbiat kendaraan bermotor. Besarnya dasar pengenaan pajak dapat berubah dari waktu kewaktu. Tarif pajak kendaraan bermotor ditetapkan sebesar: 1,5\% untuk kendaraan bermotor bukan umum; $1 \%$ untuk kenaraan bermotor umum; 0,5\% untuk kendaraan bermotor alat-alat berat dan alat-alat besar.

Besarnya pokok PKB yang terutang dihitung dengan cara mengalikan tarif pajak dengan dasar pengenaan pajak. Secara umum perhitungan $\mathrm{PKB}$ adalah sesuai dengan rumus berikut. Pajak terutang = tarif pajak $\mathrm{x}$ dasar pengenaan pajak = tarif pajak $\mathrm{x}$ (NJKB $\mathrm{x}$ Bobot) Pemungutan PKB merupakan satu kesatuan dengan pengurusan administrasi kendaraan bermotor lainnya. Khusus pemungutan PKB untuk alat-alat besar dan alat-alat berat yang bergerak dilakukan hanya oleh pemerintah daerah.

\section{METODE PENELITIAN}

Jenis metode yang digunakan dalam penelitian ini adalah metode pendekatan kualitatif. Menurut (Sugiyono, 2007) Metode Penelitian Kualitatif adalah metode penelitian yang berlandaskan pada filsafat postpositivisme (kebenaran didasarkan pada esensi/sesuai objek). Analisis data bersifat induktif/kualitatif dan hasil penelitian kualitatif lebih menekankan makna dari pada generalisasi. Berdasarkan judul yang peneliti ambil yaitu "Pelaksanaan prinsip pelayanan publik samsat Medan selatan dalam meningkatkan pemungutan pajak kendaraan bermotor roda dua", maka penelitian ini akan dilakukan di kantor UPT Samsat Medan Selatan yang beralamat JL.Sisingamangaraja km 5,5 Medan, Sumatera Utara. Adapun tekhnik pengumpulan data 
yang digunakan yaitu: Observasi, awancara, dan dokumentasi. Penelitian ini dilakukan selama satu bulan yaitu dari bulan April 2019 sampai dengan Mei 2019. Adapun metode analisis data yang digunakan antara lain: a). pengumpulan data, b) penyajian data, dan c) kesimpulan data.

\section{HASIL DAN PEMBAHASAN}

Dinas Pendapatan Daerah Provinsi Sumatera Utara pada awalnya mengurusi pengelolaan pajak dan pendapatan daerah dibawah Biro Keuangan Sekertariat Wilayah Tingkat I Sumatera Utara. Selanjutnya berdasarkan surat keputusan (SK) Gubernur Kepala Daerah Tingkat I Sumatera Utara Nomor 102'II/GSU tanggal 6 Maret 1973 tentang susunan organisasi dan tata cara kerja Sekretariat Daerah Provinsi Sumatera Utara maka Biro Keuangan ditingkatkan menjadi "Direktorat Keuangan". Dinas Pendapatan Daerah (DISPENDA) kini telah berevolusi menjadi Badan Peneglolaan Pajak dan Retribusi Daerah (BP2RD). Perubahan ini terjadi sejak terbitnya Peraturan Daerah Nomor 6 Tahun 2016 pada tanggal 20 Desember 2016 dan Peraturan Gubernur Nomor 39 Tahun 2016 pada tanggal 27 Desember 2016, Dinas Pendapatan Provinsi Sumatera Utara telah resmi berganti nama menjadi Badan Pengelolaan Pajak Dan Retribusi Daerah yang selanjutnya disingkat dengan nama BP2RD.

Samsat yang ada di Medan terdapat di tiga ilayah, salah satunya adalah di Medan Selatan yang ada di jalan Sisingamangaraja km 5,5 Medan, Sumatera Utara, dan terdapat juga gerai-gerai Samsat yang ada I jalan besar ataupun dipusat perbelanjaan di Medan. Penelitian ini menggunakan 10 prinsip Mahmudi (2005:234) yaitu sebagai berikut:

Kepastian Hukum. Kepastian Hukum berhubungan dengan peraturan perundangundangan yang menjamin terselenggaranya pelayanan publik sesuai dengan kebutuhan dan rasa keadilan masyarakat. Dalam mengukur pelaksanaan prinsip pelayanan publik sangat membutuhkan prinsip ini dikarenakan keadilan merupakan hak bagi semua masyarakat untuk mendapatkan pelayanan. Dapat disimpulkan dari hasil wawancara bahwa pelaksanaan prinsip pelayanan publik samsat Medan selatan dalam meningkatkan pemungutan pajak kendaraan bermotor roda dua cukup baik. Hal ini dapat dilihat dari pernyataan masyarakat dan petugas samsat itu sendiri. Dimana petugas berusaha bersikap adil kepada wajib pajak dalam memberikan pelayanan.

Keterbukaan. Hal ini menyatakan setiap penerima pelayanan dapat dengan mudah mengakses dan memperoleh informasi mengenai pelayanan yang diinginkan. Berdasarkan hasil wawancara dapat pula disimpulkan dari prinsip keterbukaan, bahwa pihak Samsat Medan Selatan memberikan informasi dengan cara penyuluhan, selain itu informasi mengenai pembayaran pajak juga dapat dilihat melalui Televisi ataupun radio, hal ini dapat disimpulkan bahwa keterbukaan samsat dalam menyampaikan informasi masih belum sempurna diakrenakan masih adanya masyarakat yang tidak mendapat informasi tapi datang dengan kesadaran diri sendiri.

Partisipatif. Prinsip ini berguna untuk mendorong peran serta masyarakat dalam menyelenggarakan pelayanan public dengan memperhatikan aspirasi kebutuhan dan harapan masyarakat. Berdasarkan hasil wawancara dapat pula disimpulkan dari prinsip partisipatif ini, bahwa partisipasi masyarakat untuk datang membayar pajak itu sangat 
tinggi. Tetapi dari data yang peneliti dapatkan partisipasi masyarakat untuk membayar pajak tidak sebanding dengan penerimaan pajak yang dihasilkan.

Akuntabilitas. Menurut Mardiasmo (2002) Akuntabilitas adalah sebuah keajiban melaporkan dan bertanggung jawab atas keberhasilan atapu kegagalan pelaksanaan misi organisasi dalam mencapai hasil yang telah ditetapkan sebelumnya, melalui media pertanggungjawaban yang dikerjakan secara berkala. Berdasarkan hasil wawancara dapat disimpulkan dari prinsip akuntabilitas bahwa pelaksanaan tugas yang dilakukan oleh seluruh pegawai harus dapat di pertanggungjawabkan sesuai visi dan misi Samsat Medan Selatan jika dilanggar petugas akan menerima sanksi.

Kepentingan Umum. Berhubungan dengan pemberian pelayanan publik tidak boleh mengutamakan kepentingan pribadi atau golongan. Petugas harus mendahulukan masyarakat wajib pajak dengan memberikan pelayanan tanpa mementingkan urusan pribadinya, agar tercapai tujuan yang telah ditetapkan. Berdasarkan hasil wawancara dapat disimpulkan dari prinsip kepentingan umum, bahwa petugas selalu berusaha untuk mendahulukan kepentingan masyarakat dibandingkan kepentingan pribadi. Hal ini dapat dilihat dari hasil wawancara dengan masyarakat wajib pajak yang secara langsung dilayani oleh petugas samsat Medan selatan sesuai dengan kebutuhan dan harapan masyarakat tersebut.

Profesionalisme. Menurut Siagian (2001) menyatakan bahwa yang dimaksud dengan profesionalisme adalah keandalan dalam pelaksanaan tugas srhingga terlaksana dengan mutu tinggi, waktu yang tepat, cermat, dan dengan prosedur yang mudah dipahami dan diikuti oleh pelanggan. Berdasarkan hasil wawancara dapat disimpulkan dari prinsip profesionalisme, bahwa petugas Samsat Medan Selatan masing-masing harus mempunyai kemampuan sesuai dengan bidang tugasnya. Hal ini dapat dilihat dari hasil wawancara dengan masyarakat yang secara langsung menilai kemampuan ataupun perilaku petugas samsat tersebut.

Keseimbangan Hak dan Kewajiban. Dalam pemenuhan hak harus sebanding dengan kewajiban yang harus dilaksanakan baik oleh pemberi maupun penerima layanan. Keseimbangan antara hak dan kewajiban mengandung arti bahwa di samping menuntut dan melaksanakan hak, kita harus juga mengutamakan kewajiban, contohnya seperti warga negara wajib mendapatkan pelayanan. Berdasarkan hasil wawancara dapat disimpulkan dari prinsip keseimbangan hak dan kewajiban. Keseimbangan antara hak dan kewajiban sudah cukup signifikan, karena tanggapan masyarakat wajib pajak dalam mendapatkan haknya sudah cukup terpenuhi dalam bidang pelayanan dan petugas juuga sudah berusaha untuk menjalankan kewajibannya untuk memberikan suatu pelayanan.

Sarana dan Prasarana. Berdasarkan hasil wawancara dapat disimpulkan dari prinsip Sarana Dan Prasarana, sarana dan prasarana pada samsat Medan selatan sudah cukup memadai. Hal ini dapat dilihat dari pernyataan bapak H. Ashar Nasution SE selaku kepala seksi pendataan dan penetapan dan didukung oleh pernyataan dari Ibu Duma Sari Siregar selaku masyarakat wajib pajak, bahwasanya fasilitas di samsat medan selatan ini sudah cukup baik dan membuat masyarakat yang datang nyaman ketika menunggu antrian. 
Ketepatan Waktu. Target waktu pelayanan dapat diselesaikan dalam waktu yang telah ditentukan oleh unit penyelenggaraan pelayanan. Ketepatan waktu berhubungan dengan waktu jam kerja dan berapa lama penyelesaian pembayaran pajak kendaran bermotor. Berdasarkan hasil wawancara dapat disimpulkan dari prinsip ketepatan waktu. Ketepatan aktu yang diciptakan pada Samsat Medan Selatan ini sudah cukup disiplin, dari mulai jam kerja, jam istirahat, serta waktu petugas melayani masyarakat untuk membayar pajak kendaraan bermotor.

Kecepatan, Kemudahan, dan Kejangkauan. Tempat dan lokasi serta kemudahan pelayanan yang memadai, mudah dijangkau oleh masyarakat, dapat memanfaatkan teknologitelekomunikasi informatika. Berdasarkan hasil wawancara dapat disimpulkan dari prinsip kecepatan, kemudahan, dan kejangkauan sudah cukup baik. Hal ini dapat dilihat dari pernyataan dari bapak Pardomoan Rambe dan didukung oleh pernyataan inu martina selaku wajib pajak bahwasanya kecepatan, kemudahan serta kejangkauan lokasi sudah cukup baik, mengingat dari waktu pelayanan yang hanya membutuhkanwaktu beberapa menit dan prosesnya juga mudah tidak mepersulit si wajib pajak, serta kejangkauan lokasi juga mudah dikarenakan dekat dengan jalan besar

\section{SIMPULAN}

Berdasarkan dari hasil penelitian yang telah dikemukakan dan dari hasil wawancara dapat disimpulkan, dari 10 prinsip pelayanan publik ini bahwa pelaksanaan prinsip pelayanan publik Samsat Medan Selatan dalam meningkatkan pemungutan pajak kendaraan bermotor roda dua sudah cukup baik, dan juga dapat dilihat dari data yang diperoleh yaitu realisasi penerimaan pajak kendaraan bermotor roda dua. Pelayanan yang diberikan pihak SAMSAT sudah maksimal tetapi penerimaan pajaknya tidak sesuai dengan pelayanan yang mereka berikan kepada masyarakat.

\section{DAFTAR PUSTAKA}

Mahmudi. (2005). Manajmen Kinrja Sektror Publik. Yogyakarta: UPP AMP YKPN.

Mardiasmo, D. (2002). Perpajakan Edisi 2002. Yogyakarta: Andi Yogyakarta.

Nasution, F.R. dan Rudi S.S., (2014). Evaluasi Kinerja Pegawai Kantor Samsat dalam Pelayanan Bea Balik Nama Kendaraan Bermotor, JPPUMA: Jurnal Ilmu Pemerintahan dan Sosial Politik UMA (Journal of Governance and Political UMA), 2 (1): 1-17.

Nasution, F.R. dan Rudi S.S., (2014). Evaluasi Kinerja Pegawai Kantor Samsat dalam Pelayanan Bea Balik Nama Kendaraan Bermotor, JPPUMA: Jurnal Ilmu Pemerintahan dan Sosial Politik UMA (Journal of Governance and Political UMA), 2 (1): 1-17

Rinaldi, R., (2012), Analisis Kualitas Pelayanan Publik (Studi pada Biro Umum Sekretariat Daerah Propinsi Sumatera Utara), Jurnal Administrasi Publik (Public Administration Journal), 1 (1): 22- 34

Rinaldi, R., (2012), Analisis Kualitas Pelayanan Publik (Studi pada Biro Umum Sekretariat Daerah Propinsi Sumatera Utara), Jurnal Administrasi Publik : Public Administration Journal, 1 (1): 22 - 34

Siagian, S. P. (2001). Manajemen Sumber Daya Manusia. Jakarta: Bumi Aksara.

Sinambela, L. P. (2011). Reformasi Pelayanan Publik. Jakarta: Bumi Aksara.

Sinulingga, L.O. Nasution, M.H.T. \& Batubara, B.M. (2018). Implementasi Kebijakan Pajak Progresif Bagi Kendaraan Bermotor. PERSPEKTIF, 7 (1): 19-23

Sirait, R.S.M.P., (2011), Analisis Pelayanan Publik Terhadap Administrasi Penerbitan Akta Kelahiran (Studi Pada Dinas Kependudukan Kota Medan), Jurnal Administrasi Publik (Public Administration Journal), 1 (2): 232-249

Sirait, R.S.M.P., (2011), Analisis Pelayanan Publik Terhadap Administrasi Penerbitan Akta Kelahiran (Studi Pada Dinas Kependudukan Kota Medan), Jurnal Administrasi Publik : Public Administration Journal : Public Admnistration Journal, 1 (2): 232-249

Sugiyono. (2007). Memahami Penelitian Kuantitatif, Kualitatif dan R\&D. Bandung: Alfabeta. 
Dinda Emilia, H.M.H Thamrin Nasution, Rosmala Dewi \& Indra Muda, Pelaksanaan Prinsip Pelayanan

Susanti, A., Kusmanto, H., \& Tarigan, U. (2018). Implementasi Kebijakan Pelayanan Administrasi Terpadu Kecamatan (PATEN) Terhadap Kualitas Pelayanan Publik Di Kecamatan Sidikalang Kabupaten Dairi. Publikauma : Jurnal Administrasi Publik Universitas Medan Area, 6(1), 47-57. doi:https://doi.org/10.31289/publika.v6i1.1526 